\title{
Invasive Streptococcus pyogenes infection - a retrospective clinical analysis of 6 cases
}

\author{
Inwazyjne zakażenie Streptococcus pyogenes - retrospektywna analiza kliniczna 6 przypadków
}

Department of Paediatrics, Faculty of Medical Sciences in Zabrze, Medical University of Silesia in Katowice, Zabrze, Poland

Correspondence: Michalina Malik, Department of Paediatrics, 3 Maja 13-15, 41-800 Zabrze, Poland, tel.: +4832370 42 83, fax: +4832370 42 92, e-mail: michalina.maalik@gmail.com

Abstract In recent years, there has been a rise in the number of invasive infections caused by Streptococcus pyogenes. The reasons for the observed increased prevalence of the disease are not entirely clear. The present study describes the cases of 6 children hospitalised over a course of one year with a diagnosis of invasive infection due to this pathogen. Three patients were diagnosed with acute post-streptococcal glomerulonephritis and pneumonia (complicated by pleural empyema in 1 patient). Two patients had erysipelas (including one case of recurrent erysipelas), and 1 patient was found to have an abscess in the border area between the femur and soft tissues. The study analyses the clinical course of infection, and highlights the importance of diagnostic tests, particularly the antistreptolysin $\mathrm{O}$ titre test, in confirming the infection triggered by Streptococcus pyogenes.

Keywords: Streptococcus, children, pneumonia, abscess, diagnostics

Streszczenie $\quad$ W ostatnich latach obserwuje się wzrost inwazyjnych zakażeń wywołanych przez Streptococcus pyogenes. Przyczyny wzrostu zachorowań nie są do końca jasne. W pracy opisano przypadki 6 dzieci hospitalizowanych w ciągu roku z rozpoznanym inwazyjnym zakażeniem tym patogenem. U 3 pacjentów stwierdzono ostre popaciorkowcowe zapalenie nerek oraz zapalenie płuc (powikłane u 1 pacjenta ropniakiem opłucnej), u 2 dzieci różę, w tym 1 przypadek róży nawrotowej, u 1 dziecka ropień na granicy kości udowej i tkanek miękkich. W pracy przeanalizowano przebieg kliniczny zakażenia oraz znaczenie badań diagnostycznych, w szczególności miana antystreptolizyny O, w potwierdzeniu zakażenia wywołanego przez Streptococcus pyogenes.

Słowa kluczowe: Streptococcus, dzieci, zapalenie płuc, ropień, diagnostyka 


\section{INTRODUCTION}

S treptococcus pyogenes, i.e. group A (beta-haemolytic) Streptococcus (GAS) is a species of Gram-positive, catalase-negative coccal bacterium in the genus Streptococcus which currently includes more than 50 species. Streptococci induce infections in a wide variety of hosts, ranging from humans to multiple species of domestic and wild animals. They are known to cause a broad array of infections of varying severity ${ }^{(1)}$. Despite great advances in medicine and the possibility to use penicillin, an antibiotic that remains fully active against $S$. pyogenes, the incidence of infections caused by this pathogen is still high all over the world $^{(2)}$. S. pyogenes-induced infections are primarily noninvasive, and mostly sporadic. The most common types include tonsillopharyngitis (strep throat), occurring especially in temperate countries; superficial dermatitis (impetigo), more prevalent in warm and humid climates; but also scarlet fever, paranasal sinusitis, otitis media or vaginitis. Based on estimates, GAS leads to 616 million new cases of pharyngitis and 111 million cases of skin infections (chiefly impetigo) globally each year ${ }^{(3,4)}$. Certain manifestations of GAS infection, though relatively rare, are invasive, i.e. developing in physiologically sterile body sites. They include mild to moderately severe infections, such as cellulitis, bacteraemia, erysipelas, myositis, pneumonia, puerperal infection, arthritis, as well as severe infections, for example streptococcal toxic shock syndrome (STSS), fasciitis, and meningitis ${ }^{(1,5,6)}$. There is also a risk of severe non-purulent immune-mediated sequelae (rheumatic fever, glomerulonephritis) which may develop in the second to third week after streptococcal pharyngitis, usually in young untreated individuals ${ }^{(1,7,8)}$.

GAS infections spread by droplet transmission or by direct contact with nasopharyngeal secretions of an affected person or a carrier. The transmission of the pathogen can also occur through contact with infected wounds or pathologically altered skin. The incubation period varies: for pharyngitis and tonsillitis it ranges from 2 to 5 days, while for skin infections it is slightly longer, between 5 and 7 days. Studies suggest that schoolchildren may be the reservoir of GAS infection and spread in the home environment on account of their high morbidity risk and prevalent carrier status. Children from this group are frequently affected by viral infections of the upper respiratory tract, which increases the transmission of $S$. pyogenes and other species inhabiting the nasopharynx ${ }^{(8,9)}$.

\section{INVASIVE INFECTIONS}

Since the 1980s, there has been a steady rise in invasive group A Streptococcus disease (iGASD) infections, both in adults and children, including infections with a severe clinical course $\mathrm{e}^{(9,10)}$. In Europe, the incidence of iGASD ranges between 0.4 and 4.8 cases per 100,000 individuals per year, with mortality rates in children estimated to vary from 0 to $14 \%^{(11)}$. The risk factors for and the time period of 4 weeks postpartum. Comorbidities associated with an increased risk of invasive infection with the pathogen include heart diseases, diabetes, malignant tumours, and obesity ${ }^{(12)}$. The risk of iGASD increases by 40 -fold (up to 60 -fold) within 2 weeks of the onset of symptoms of chickenpox $^{(7)}$. In addition, an elevated susceptibility to secondary bacterial infections, including S. pyogenes, has also been demonstrated in patients after influenza, which is probably associated with an increased synthesis of interleukins IL-1 $\beta$ and IL-10 $0^{(7,13)}$. Treatment with non-steroidal anti-inflammatory drugs may be an indirect risk factor for necrotising fasciitis or STSS arising in the mechanism of delayed introduction of targeted antibiotic therapy. Also, any break in the continuity of the skin is a potential gateway to infection ${ }^{(14)}$.

\section{PROTEIN AND INVASIVENESS}

The main adhesin and, at the same time, a pivotal virulence factor of GAS is M protein, originally identified by Rebecca Lancefield over 80 years ago. Since its discovery, M protein has been extensively studied, and new insights are gained into its structure and role in the pathogenesis of GAS. A key contributory factor to the process was the sequencing the entire bacterial genome of many strains of S. pyogenes ${ }^{(5,7)}$. $M$ protein is arguably one of the best described bacterial factors responsible for the virulence of $S$. pyogenes. Its complex structure, function, immunochemical properties, and antigenic variation appear quite unique. Currently, more than 90 serotypes and over $200 \mathrm{emm}$ types of M protein are known, with specific serological types corresponding to genetic types. It has been shown that invasive GAS infections are most typically associated with the emm types $1,3,12,28$, 89 , with type 1 being most commonly identified in iGASD cases in developed countries ${ }^{(5,7)}$.

Over the past 10 years, there has been a surge in cases of scarlet fever which is believed to be attributable to the emergence of a distinct breakaway emm 1 clone referred to as $\mathrm{M}_{1} \mathrm{UK}^{(5,15)}$.

\section{AIM OF THE PAPER}

The aim of the study was to perform a retrospective analysis of the clinical course of invasive infection caused by S. pyogenes in children hospitalised during a period of 1 year.

\section{MATERIALS AND METHODS}

Tab. 1 lists the basic demographic data, diagnostic test results, types of treatment, and the clinical course of infection in six children ( 4 girls and 2 boys, aged 4-7 years) hospitalised with suspected invasive $S$. pyogenes infection.

\section{RESULTS}

In 2018, a total of 625 children received urgent treatment in the General Paediatrics Department at Prof. Stanisław 


\begin{tabular}{|c|c|c|c|c|c|}
\hline \begin{tabular}{|c|} 
Patient number, \\
initials, age and sex
\end{tabular} & $\begin{array}{l}\text { Concomitant } \\
\text { diseases }\end{array}$ & $\begin{array}{c}\text { Symptoms and physical } \\
\text { examination findings }\end{array}$ & Test results & Clinical course & $\begin{array}{l}\text { Final diagnosis; } \\
\text { month }\end{array}$ \\
\hline 1. F.L., 5 years old, $Q$ & $\begin{array}{l}\text { Inhaled allergy, } \\
\text { innocent murmur }\end{array}$ & $\begin{array}{l}\text { Fair general condition; } \\
\text { obesity. Auscultation } \\
\text { findings: diminished } \\
\text { vesicular breath sounds } \\
\text { over the lung fields, } \\
\text { isolated crackles over } \\
\text { the left lung field }\end{array}$ & 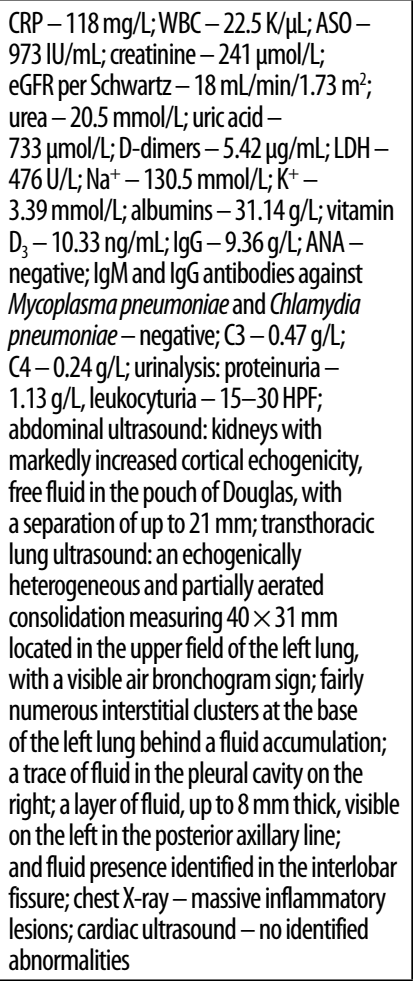 & $\begin{array}{l}\text { Five days before hospital admission, } \\
\text { the child had acute laryngitis and } \\
\text { fever (treated with an oral antibiotic- } \\
\text { azithromycin), symptoms } \\
\text { of gastroenteritis and oliguria; } \\
\text { antibiotic therapy and parenteral } \\
\text { hydration were provided; after } \\
8 \text { days, an improvement of the } \\
\text { patient's clinical condition was } \\
\text { noted, along with normalisation } \\
\text { of the complement C3 component } \\
\text { and partial normalisation of other } \\
\text { laboratory parameters including } \\
\text { a significant improvement in renal } \\
\text { function (eGFR } 68 \mathrm{~mL} / \text { min/1.73 } \mathrm{m}^{2} \text { ), } \\
\text { normalisation of uric acid and } \\
\text { urea levels, and an increase in the } \\
\text { antistreptolysin titre to the level } \\
\text { of } 1,029 \mathrm{IU} / \mathrm{mL} \text {; chest X-ray showed } \\
\text { improved aeration of the lower and } \\
\text { middle left lung fields, and enhanced } \\
\text { hilar and parahilar pattern on the } \\
\text { right, with the greatest intensity } \\
\text { observed in the lower lung field }\end{array}$ & $\begin{array}{l}\text { Acute post- } \\
\text { streptococcal } \\
\text { glomerulonephritis; } \\
\text { pneumopleuritis; } \\
\text { October }\end{array}$ \\
\hline 2. P.P., 5 years old, $Q$ & $\begin{array}{l}\text { Suspicion of } \\
\text { bronchial asthma }\end{array}$ & $\begin{array}{l}\text { Oedema of the eyelids } \\
\text { and face; discreetly } \\
\text { diminished vesicular } \\
\text { breath sounds over the } \\
\text { lung fields on the right; } \\
\text { haematuria }\end{array}$ & 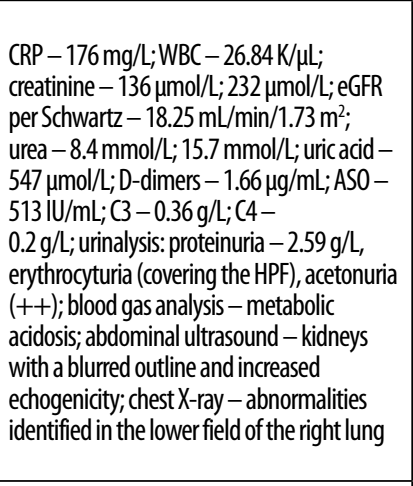 & $\begin{array}{l}\text { Two days before hospital admission, } \\
\text { the child had a respiratory infection; } \\
\text { intravenous antibiotic therapy } \\
\text { (ceftriaxone) was initiated in the } \\
\text { district hospital; } 2 \text { days prior to } \\
\text { admission, the patient showed } \\
\text { signs of acute renal failure with } \\
\text { a significantly reduced eGFR; } \\
\text { the treatment included antibiotic } \\
\text { therapy, intravenous hydration, } \\
\text { and nebulised budesonide; after the } \\
\text { normalisation of clinical parameters, } \\
\text { the child was discharged home, } \\
\text { and the parents were instructed } \\
\text { to continue antibiotic therapy } \\
\end{array}$ & $\begin{array}{l}\text { Acute post- } \\
\text { streptococcal } \\
\text { glomerulonephritis; } \\
\text { pneumonia; 0ctober }\end{array}$ \\
\hline 3. D.P., 6 years old, $0^{7}$ & $\begin{array}{l}\text { Obesity, history } \\
\text { of chickenpox } \\
\text { at the age } \\
\text { of } 4.5 \text { years }\end{array}$ & $\begin{array}{l}\text { Erythematous lesion located } \\
\text { on the right lower leg } \\
\text { (Fig. 1) - oedema, redness } \\
\text { and excessively warm skin, } \\
\text { approx. } 7 \mathrm{~cm} \text { in diameter, } \\
\text { a small scab in the centre } \\
\text { of the lesion, tenderness to } \\
\text { palpation within the right } \\
\text { lower leg and thigh, and } \\
\text { reactive enlargement of the } \\
\text { inguinal lymph nodes on } \\
\text { the right; tinea versicolor- } \\
\text { type lesions on the skin } \\
\text { of the abdomen; excess } \\
\text { subcutaneous fat } \\
\text { (BMI } 21.2 \mathrm{~kg} / \mathrm{m}^{2}, \\
\text { i.e. }>97^{\text {th }} \text { percentile) }\end{array}$ & $\begin{array}{l}\text { CRP - } 100.51 \mathrm{mg} / \mathrm{L} ; \mathrm{WBC}-23.5 \mathrm{~K} / \mu \mathrm{L} ; \\
\text { predominance of neutrophils }-87.1 \% ; \\
\text { ASO - } 1,355 \mathrm{IJ} / \mathrm{mL} ; \mathrm{D} \text {-dimers }-0.83 \mu \mathrm{\mu g} / \mathrm{mL} ; \\
\text { urinalysis - acetonuria (+++++); blood } \\
\text { culture and throat swab test - sterile; } \mathrm{X} \text {-ray } \\
\text { of the lower leg - soft tissue oedema, } \\
\text { no bone pathologies; X-ray of the pelvis } \\
\text { and hips - no identified abnormalities; } \\
\text { ultrasound of the right groin - an oval } \\
\text { lymph node with a thickened cortex and } \\
\text { hilar vascularity (measuring } 2.6 \times 0.8 \mathrm{~cm} \text { ); } \\
\text { abdominal ultrasound }- \text { no abnormalities } \\
\text { except for a large amount of bowel gas }\end{array}$ & $\begin{array}{l}\text { Seven days before hospitalisation, } \\
\text { the child sustained a minor injury to } \\
\text { the right lower leg involving a break } \\
\text { in skin continuity; an initially good } \\
\text { healing response was followed by } \\
\text { a gradual increase in swelling and } \\
\text { redness, increased warmth and } \\
\text { tenderness of the right lower leg, } \\
\text { accompanied by fever up to } 39^{\circ} C \text {; } \\
\text { the infection was initially treated } \\
\text { with topical mupirocin; in addition } \\
\text { to antibiotic therapy, the patient } \\
\text { received intravenous hydration and } \\
\text { thromboprophylaxis; the child's } \\
\text { general condition improved, with } \\
\text { a gradual reduction of erythema } \\
\text { and normalisation of inflammatory } \\
\text { parameters }\end{array}$ & $\begin{array}{l}\text { Erysipelas of the right } \\
\text { lower leg; November }\end{array}$ \\
\hline
\end{tabular}

Tab. 1. Clinical course of invasive infection caused by S. pyogenes in hospitalised children

Szyszko Independent Public Research and Teaching Hospital no. 1 in Zabrze, Poland. Invasive infections with S. pyogenes accounted for less than $1 \%$ of all hospitalisations in the Department. All the infections occurred during the autumn and winter, between September and March. No significant factors predisposing to infection were found in any of 


\begin{tabular}{|c|c|c|c|c|c|}
\hline $\begin{array}{c}\text { Patient number, } \\
\text { initials, age and sex }\end{array}$ & $\begin{array}{l}\text { Concomitant } \\
\text { diseases }\end{array}$ & $\begin{array}{l}\text { Symptoms and physical } \\
\text { examination findings }\end{array}$ & Test results & Clinical course & $\begin{array}{l}\text { Final diagnosis; } \\
\text { month }\end{array}$ \\
\hline 4. S.F., 6 years old, O' & \begin{tabular}{|l|} 
Pharyngeal \\
tonsillar \\
hypertrophy, \\
vision defect - \\
right eye: +5.5 D, \\
left eye: +6.5 D
\end{tabular} & $\begin{array}{l}\text { General condition fairly } \\
\text { good; slight swelling of the } \\
\text { eyelids and the left upper } \\
\text { limb; rhinitis, hypertrophic } \\
\text { tonsils; palpable small } \\
\text { nuchal lymph nodes; } \\
\text { auscultation findings: } \\
\text { crackles over the middle } \\
\text { and lower lobes of the right } \\
\text { lung, diminished vesicular } \\
\text { breath sounds at the base } \\
\text { of the right lung; liver } \\
\text { protruding approx. } 2 \mathrm{~cm} \\
\text { from under the costal arch }\end{array}$ & 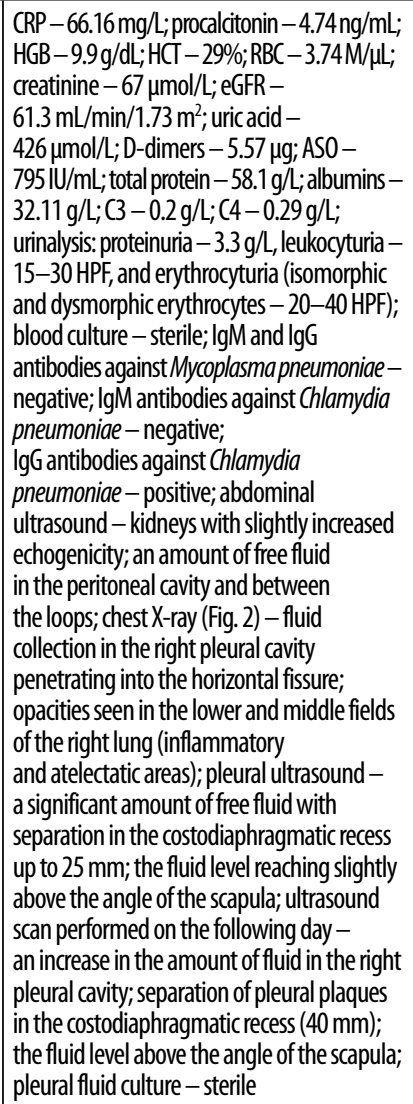 & $\begin{array}{l}\text { Five days before hospital admission, } \\
\text { the child had a cough, fever up to } \\
39.5^{\circ} \text { Cand recurrent pain in the } \\
\text { right subcostal area, and received } \\
\text { intravenous antibiotic therapy } \\
\text { in the district hospital; on the } \\
5^{\text {th }} \text { day of hospitalisation, } \\
\text { the patient underwent thoracoscopy, } \\
\text { parietal pleura biopsy, pleural lavage } \\
\text { and drainage; the therapeutic } \\
\text { management included antibiotic } \\
\text { treatment, intravenous hydration, } \\
\text { antifungal and anticoagulant } \\
\text { drugs, and antihypertensive agents; } \\
\text { an improvement in the child's } \\
\text { general condition was achieved, } \\
\text { but proteinuria, haematuria and } \\
\text { hypertension associated with } \\
\text { kidney disease persisted; further } \\
\text { nephrological follow-up was } \\
\text { prescribed }\end{array}$ & $\begin{array}{l}\text { Pneumonia; pleural } \\
\text { empyema; acute } \\
\text { post-streptococcal } \\
\text { glomerulonephritis; } \\
\text { January }\end{array}$ \\
\hline 5. P.F., 4 years old, ㅇ & None & $\begin{array}{l}\text { General condition: fairly } \\
\text { good; forced position } \\
\text { of the right lower limb; } \\
\text { the skin of the right } \\
\text { thigh excessively warm, } \\
\text { palpable thickening and } \\
\text { tenderness in the area; } \\
\text { oedema - the width } \\
\text { of the right thigh } 2 \mathrm{~cm} \\
\text { larger than that of the } \\
\text { left thigh; palatine tonsils } \\
\text { enlarged, with coating; } \\
\text { soft systolic murmur over } \\
\text { the heart }\end{array}$ & $\begin{array}{l}\text { CRP }-226.46 \mathrm{mg} / \mathrm{L} ; \text { procalcitonin - } \\
2.9 \mathrm{ng} / \mathrm{mL} ; \mathrm{HGB}-10 \mathrm{~g} / \mathrm{dL} ; \mathrm{HCT}-29.2 \% \text {; } \\
\mathrm{RBC}-3.96 \mathrm{M} / \mathrm{\mu L} ; \mathrm{ASO}-861 \mathrm{IU} / \mathrm{mL} ; \\
\mathrm{D}-\text { dimers }-3.32 \mu \mathrm{\mu g} / \mathrm{mL} ; \text { fibrinogen - } \\
8.54 \mathrm{~g} / \mathrm{L} ; \text { vitamin } \mathrm{D}_{3}-17.17 \mathrm{ng} / \mathrm{mL} ; \\
\text { IgM antibodies against Borrelia - } \\
78.25 \mathrm{RU} / \mathrm{ml} \text { (elevated). IgG antibodies } \\
\text { against Borrelia }-4.54 \mathrm{RU} / \mathrm{mL}- \\
\text { negative; Western Blot test for Borrelia } \\
\text { burgdorferi (IgG) - negative; pelvic } \\
\text { X-ray - exclusion of traumatic lesions; } \\
\text { ultrasound of the right thigh performed } \\
\text { on admission and Doppler ultrasound } \\
\text { of the venous system of the lower limb - } \\
\text { no identified abnormalities; MRI of the } \\
\text { right thigh with contrast - features } \\
\text { of osteomyelitis at } 1 / 2 \text { of the distal right } \\
\text { femur, suspected narrow fistula tract } \\
\text { and an abscess in the border area } \\
\text { between the femur and soft tissues } \\
\text { at the distal } 1 / 3 \text { of the posterior thigh }\end{array}$ & $\begin{array}{l}\text { Four days before hospital admission, } \\
\text { the child developed fever and pain } \\
\text { in both legs, and was hospitalised } \\
\text { inthe paediatric department in the } \\
\text { district hospital. Streptest positive, } \\
\text { CRP } 330 \text { mg/L; the consulting } \\
\text { surgeon diagnosed deep fasciitis } \\
\text { of the right thigh; intravenous } \\
\text { antibiotic therapy (ceftriaxone and } \\
\text { clindamycin) was administered and } \\
\text { continued during the patient's stay in } \\
\text { other hospital departments; on day } \\
8 \text { of hospitalisation in the General } \\
\text { Paediatric Department, after MR } \\
\text { examination of the leg, the child } \\
\text { was transferred to the Paediatric } \\
\text { Surgery Department to undergo } \\
\text { decompression of the abscess cavity } \\
\text { by core needle biopsy; no bacterial } \\
\text { growth was obtained in the biopsy } \\
\text { material; treatment: intravenous } \\
\text { antibiotics, anticoagulants, analgesics; } \\
\text { normalisation of inflammatory } \\
\text { parameters, gradual regression of } \\
\text { the abscess; continued oral antibiotic } \\
\text { therapy (clindamycin) and follow-up } \\
\text { evaluation in the Surgery Outpatient } \\
\text { Clinic }\end{array}$ & $\begin{array}{l}\text { Abscess located in the } \\
\text { border area between } \\
\text { the femur and soft } \\
\text { tissues; osteomyelitis; } \\
\text { acute streptococcal } \\
\text { tonsillopharyngitis; } \\
\text { March }\end{array}$ \\
\hline
\end{tabular}

Tab. 1. Clinical course of invasive infection caused by S. pyogenes in hospitalised children (cont.)

the patients. Prior to admission, a total of five children were treated with systemic antibiotics, and the patient with erysipelas received topical treatment. In all the children, laborato- markers: C-reactive protein (CRP) (66-226 mg/L), leukocytosis (up to $26.84 \mathrm{~K} / \mu \mathrm{L}$ ), and high antistreptolysin $\mathrm{O}$ (ASO) titres in 5 children (up to $1,355 \mathrm{IU} / \mathrm{mL}$ ). In the child with recurrent erysipelas, the ASO titre was shown to have increased 


\begin{tabular}{|c|c|c|c|c|c|}
\hline $\begin{array}{c}\text { Patient number, } \\
\text { initials, age and sex }\end{array}$ & $\begin{array}{l}\text { Concomitant } \\
\text { diseases }\end{array}$ & $\begin{array}{c}\text { Symptoms and physical } \\
\text { examination findings }\end{array}$ & Test results & Clinical course & $\begin{array}{l}\text { Final diagnosis; } \\
\text { month }\end{array}$ \\
\hline 6. C.Z., 7 years old, $Q$ P & None & $\begin{array}{l}\text { General condition: fair; } \\
\text { multiple signs of mosquito } \\
\text { bites covered with scabs } \\
\text { found all over the body, } \\
\text { including the left lower leg; } \\
\text { oedema of the left lower } \\
\text { leg; the skin on the lower } \\
\text { leg is tight, with a fairly } \\
\text { well demarcated area of } \\
\text { erythema, tender and very } \\
\text { warm to palpation, with } \\
\text { vesicular lesions forming } \\
\text { on the surface; the throat } \\
\text { appears red, and the tonsils } \\
\text { are enlarged, showing no } \\
\text { coating }\end{array}$ & $\begin{array}{l}\text { CRP - } 226 \mathrm{mg} / \mathrm{L} ; \text { procalcitonin - } \\
3.86 \mathrm{ng} / \mathrm{mL} ; \mathrm{WBC} \text { - } 19.94 \mathrm{~K} / \mu \mathrm{L} \text {; } \\
\text { ASO - } 102 \text { IU/mL; D-dimers - } \\
1.23 \mu \mathrm{m} / \mathrm{mL} \text {; total IgE antibodies - } \\
\text { elevated.; IgM antibodies against } \\
\text { Borrelia - positive; IgG antibodies } \\
\text { against Borrelia - negative; Western Blot } \\
\text { test for Borrelia burgdorferi } \\
\text { (IgM and IgG) - negative; ANA - } \\
\text { negative; blood culture - sterile; } \\
\text { urinalysis - acetonuria (++); } \\
\text { nasopharyngeal and skin swabs - } \\
\text { negative; } X \text {-ray of the lower leg: } \\
\text { the bone structures visualised on X-ray } \\
\text { revealed no post-traumatic sequelae }\end{array}$ & $\begin{array}{l}\text { Two days prior to hospital admission, } \\
\text { the child sustained an injury to the } \\
\text { left lower leg; gradually increasing } \\
\text { oedema of the left leg was observed, } \\
\text { with fever to } 39.2^{\circ} \text {; } \text { oral antibiotic } \\
\text { therapy was prescribed on an } \\
\text { outpatient basis; vomiting occurred; } \\
\text { the child was treated with antibiotics } \\
\text { and given intravenous hydration; } \\
\text { a significant improvement was } \\
\text { observed in the left lower leg, though } \\
\text { with persistent oedema of the lower } \\
\text { leg down to the foot; mild redness } \\
\text { and warmth were noted in the } \\
\text { affected area; partial normalisation } \\
\text { of laboratory parameters was } \\
\text { achieved; the girl was discharged } \\
\text { home at the request of her father }\end{array}$ & $\begin{array}{l}\text { Erysipelas of the left } \\
\text { lower leg; September }\end{array}$ \\
\hline 6a. C.Z., 7 years old,,+ & None & $\begin{array}{l}\text { General condition: fairly } \\
\text { good; excessively warm } \\
\text { skin; oedema, redness, } \\
\text { tenderness to palpation } \\
\text { within the left lower leg; } \\
\text { oedema of the left ankle; } \\
\text { multiple signs of insect } \\
\text { bites on the skin of the } \\
\text { lower limbs }\end{array}$ & $\begin{array}{l}\text { CRP - } 129 \mathrm{mg} / \mathrm{L} ; \text { procalcitonin - } \\
2.55 \mathrm{ng} / \mathrm{mL} ; \mathrm{WBC} \text { - } 19.17 \mathrm{~K} / \mu \mathrm{L} ; \\
\text { ASO - } 203 \mathrm{IU} / \mathrm{mL} \text {; D-dimers - } \\
0.54 \mu \mathrm{\mu g} / \mathrm{mL} \text {; blood culture - sterile; } \\
\text { ANA - negative; skin lesion swab - } \\
\text { negative; nasopharyngeal swab - } \\
\text { S. pyogenes; stool parasite test - } \\
\text { positive; urinalysis - dysmorphic } \\
\text { erythrocytes, hyaline casts }\end{array}$ & Disease recurrence & $\begin{array}{l}\text { Erysipelas of the left } \\
\text { lower leg; reactive } \\
\text { post-streptococcal } \\
\text { glomerulonephritis; } \\
\text { giardiasis; October }\end{array}$ \\
\hline \multicolumn{6}{|c|}{$\begin{array}{l}\text { ANA - anti-nuclear antibodies; } \text { ASO - antistreptolysin } 0 \text { test; BMI - body mass index; CRP - C-reactive protein; eGFR - estimated glomerular filtration rate; } \\
\text { IgE, IgG, IgM - immunoglobulins E, G, M; HCT - haematocrit; HGB - haemoglobin; } \mathbf{L D H} \text { - lactate dehydrogenase; MR - magnetic resonance; } \mathbf{R B C} \text { - red blood cells; } \\
\text { WBC - white blood cells. } \\
\text { Reference ranges for selected parameters: CRP <5 mg/L; procalcitonin } 0.1-0.5 \mathrm{ng} / \mathrm{mL} ; A S 010-100 \mathrm{IU} / \mathrm{mL} \text {. }\end{array}$} \\
\hline
\end{tabular}

Tab. 1. Clinical course of invasive infection caused by S. pyogenes in hospitalised children (cont.)

from 102 to $203 \mathrm{IU} / \mathrm{mL}$. One patient had a positive StrepTest result, and in another one $S$. pyogenes was cultured from a nasal and throat swab. Blood cultures were performed in 3 patients, but no bacteria were grown. Where a complement test was performed, a decreased level of the $\mathrm{C} 3$ component of the complement system was shown. Based on the chest X-ray findings, inflammatory changes in the lungs were identified in 3 children, with pleural involvement shown in 2 of them. In children with acute post-streptococcal glomerulonephritis, changes in urine parameters including proteinuria (1.13-3.3 g/L), erythrocyturia, and leukocyturia, were detected.

The final clinical diagnoses were: acute post-streptococcal glomerulonephritis and pneumonia in 3 children (complicated by pleuritis in 1 patient, and by pleural empyema in another), erysipelas in 2 children, and an abscess in the border area between the femur and soft tissues in 1 child. A total of 2 patients required surgical intervention (thoracoscopy, abscess puncture).

\section{DISCUSSION}

The paper presents a retrospective analysis of the clinical course of invasive GAS infection in children hospitalised over a period of one year. Certain doubts may arise as to the diagnosis of invasive $S$. pyogenes infection solely on the basis of the clinical findings and high ASO titres, without bacteriological confirmation.
In children, microbiological confirmation of iGASD is usually performed in severe and very severe cases, and it is obtained in $85 \%$ of patients. Using conventional culture media, $S$. pyogenes is most commonly grown from biological material collected from abscesses, and least frequently from blood $^{(10)}$. It needs to be noted that all of the children reported in this study were treated with antibiotics prior to their diagnosis.

The body's immune response to $S$. pyogenes infection is known to involve the synthesis of a number of antibodies against the streptococcal cellular and extracellular components. Specific antibodies to various $S$. pyogenes serotypes, as well as antibodies to cellular antigens, are usually determined in scientific studies ${ }^{(16)}$. The serological diagnostic work-up in cases of suspected S. pyogenes infection is based on the body's immune response against extracellular enzymes such as streptolysin O, DNase B, hyaluronidase, and streptokinase. Routinely, infections are confirmed on the basis of ASO titre levels. The method involving ASO titre measurement was first proposed by Todd in $1932^{(17)}$.

The ASO titre is an important serological marker of acute GAS infection. The ASO level begins to rise a week after infection, and within approximately 3 to 6 weeks it reaches peak values which may persist for several months. A marked rise in the ASO titre is observed in patients with throat infections and rheumatic fever ${ }^{(16)}$. Considering that the proportion of asymptomatic carriers of $S$. pyogenes in the upper 


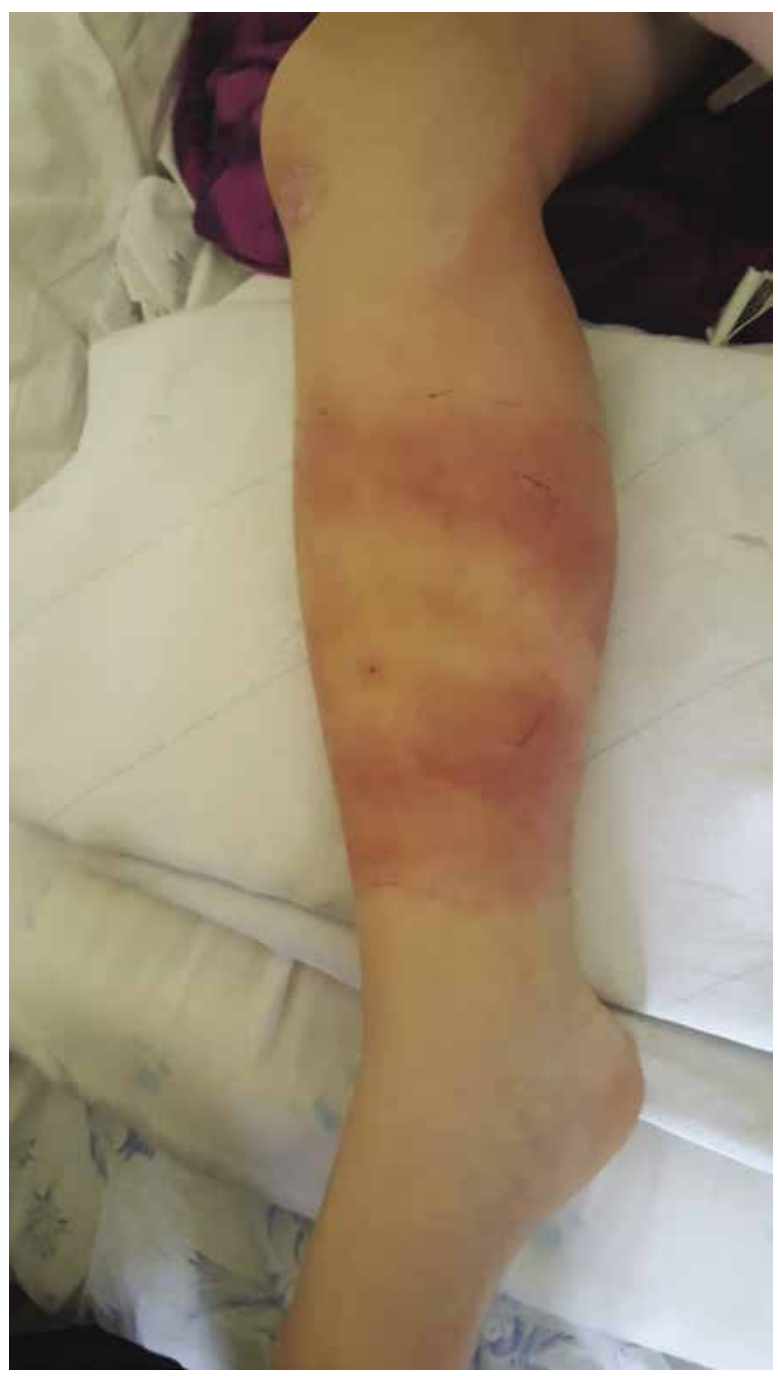

Fig. 1. Erysipelas on the lower leg - patient 3

respiratory tract is relatively high in the general population (12-23\% of school-aged children, $5 \%$ of adults $\left.{ }^{(8)}\right)$, it is recognised that the reference method in the diagnostic workup of GAS infection should be a double ASO titre test: one performed at the beginning of infection and the other at least 14 days after the onset of symptoms. In clinical practice, a single high ASO titre in most cases may be interpreted as a past GAS infection ${ }^{(18)}$. ASO titres $\geq 166 \mathrm{IU} / \mathrm{mL}$ are widely recognised as a reliable sign of having a recent streptococcal infection ${ }^{(19)}$. However, when interpreting the ASO titre, all the factors affecting it, such as age, sex, climatic zone, and antibiotic therapy, should be taken into account. In the studied patients, the ASO titre was determined in the first or second week of disease, showing values above the accepted reference range. In the majority of children, blood culture was not performed because of a previously initiated antibiotic regimen. Also, there was no possibility to perform molecular tests that would increase the sensitivity of S. pyogenes antigen detection by analysing the genetic material of the pathogen. M protein gene (emm type) analysis is

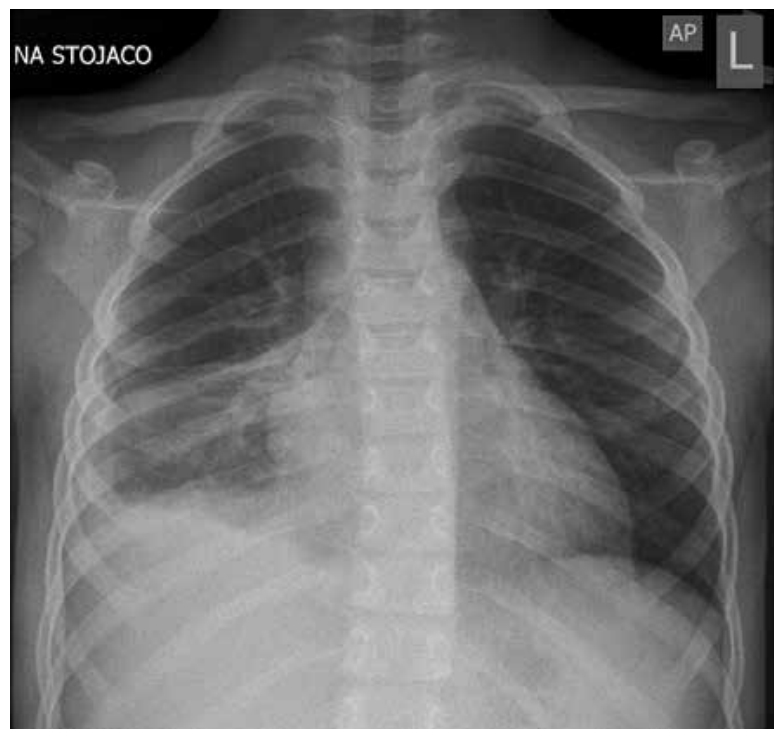

Fig. 2. Inflammatory and atelectatic areas in the right lungpatient 4

on the sequencing of selected DNA fragments, it detects even the smallest differences in their structure. However, the availability of this test is still limited ${ }^{(8)}$.

In three children included in our study, pneumonia was associated with acute glomerulonephritis, which is rarely reported in the literature ${ }^{(20)}$. Symptoms of glomerulonephritis occur 5-21 days after pharyngitis and upper respiratory tract inflammation or within 3-4 weeks after dermatitis, as confirmed by reported cases ${ }^{(6,21)}$.

Available epidemiological data show that the prevalence of pneumonia caused by $S$. pyogenes is on a rise, currently accounting for $4.9 \%$ of all pneumonia cases in children ${ }^{(10)}$. This may be linked to reduced nasopharyngeal colonisation by Streptococcus pneumoniae vaccine serotypes, which paradoxically promotes colonisation by non-vaccine pneumococcal serotypes or other potential pathogens, including S. pyogenes. There has also been a surge in the incidence of complications (including pleural empyema and pleural effusion) which are associated with GAS infection in 19\% of cases $^{(22)}$.

$50 \%$ of patients develop necrotising fasciitis/osteonecrosis, with the gateway for infection remaining unidentified. The infection begins deep within the tissues, often at the site of haematoma, muscle strain, or traumatic joint injury. Most likely, the bacteria move through the bloodstream from the throat to deep soft tissues. Importantly, the process does not require a history of or ongoing streptococcal pharyngitis, as infection may occur as a result of being a carrier ${ }^{(4,14)}$. The soft tissue abscess located on the thigh in the girl included in the study was preceded by pharyngitis. Erysipelas is a relatively common disease, especially in the elderly, and less prevalent in children and newborns ${ }^{(4,23)}$. Risk factors include obesity, cachexia, and conditions associated with immunodeficiency. Recurrent erysipelas may occur as a result of inappropriate treatment of infection, 
such as insufficient antibiotic dose or duration of therapy, failure to elevate the affected limb, skin damage which may act as the gateway to infection (untreated mycosis, ulcers), persistent limb oedema, or chronic venous insufficiency ${ }^{(23)}$. It is important to note that the cutaneous manifestations of S. pyogenes infection are not usually accompanied by an increase in the ASO titre, or the titre is lower than in patients with upper respiratory tract infections, a possible reason being that the activity of streptolysin $\mathrm{O}$ is inhibited by cholesterol in the subcutaneous tissue ${ }^{(4)}$. Consequently, accurate diagnosis can be facilitated by determining the titre of anti-DNase B, which has a tendency to rise in patients with skin infections caused by $S$. pyogenes ${ }^{(4)}$. Recurrent erysipelas in the girl included in the present study can be attributed to $S$. pyogenes as the aetiological factor based on the characteristic cutaneous features: erythematous lesions that are clearly distinct from the surrounding healthy tissue, history of an injury with a break in skin continuity, detection of S. pyogenes in the throat, and a twofold increase in the ASO titre in tests carried out within 1 month.

\section{CONCLUSIONS}

In our study, children diagnosed with invasive GAS infections accounted for a small percentage of hospitalised patients. The clinical findings in the analysed iGASD cases were dominated by pneumonia associated with glomerulonephritis. Based on the available epidemiological data, the role of S. pyogenes should always be considered in the aetiology of severe pneumonia. In light of limited availability of advanced methods for S. pyogenes detection and antibiotic therapy initiated prior to hospitalisation, the diagnostic work-up for suspected iGASD should include an assessment of the clinical course of the disease in conjunction with the ASO test result.

\section{Conflict of interest}

The authors do not declare any financial or personal links with other persons or organisations that might adversely affect the content of the publication or claim any right to the publication.

\section{References}

1. Szczypa K, Wilemska J, Hryniewicz W et al.: Mechanizmy wirulencji Streptococcus pyogenes. Post Mikrobiol 2012; 51: 3-15.

2. Meyer Sauteur PM, Burkhard A, Moehrlen U et al.: Pleural tapguided antimicrobial treatment for pneumonia with parapneumonic effusion or pleural empyema in children: a single-center cohort study. J Clin Med 2019; 8: 698.

3. Carapetis JR, Steer AC, Mulholland EK et al.: The global burden of group A streptococcal diseases. Lancet Infect Dis 2005; 5: 685-694.

4. Stevens DL, Bryant AE: Impetigo, erysipelas and cellulitis. In: Ferretti JJ, Stevens DL, Fischetti VA (eds.): Streptococcus pyogenes: Basic Biology to Clinical Manifestations [Internet]. University of Oklahoma Health Sciences Center, Oklahoma City (OK) 2016-. Available from: https://www.ncbi.nlm.nih.gov/ books/NBK333408/ [cited: 27 January 2020].
5. Barnett TC, Bowen AC, Carapetis JR: The fall and rise of Group A Streptococcus diseases. Epidemiol Infect 2018; 147: 1-6.

6. Khan ZZ, Salvaggio MR: Group A streptococcal (GAS) infections. Medscape [updated 2018 Sep. 07]. Available from: https:// emedicine.medscape.com/article/228936-overview [cited: 27 January 2020].

7. Efstratiou A, Lamagni T: Epidemiology of Streptococcus pyogenes. In: Ferretti JJ, Stevens DL, Fischetti VA (eds.): Streptococcus pyogenes: Basic Biology to Clinical Manifestations [Internet]. University of Oklahoma Health Sciences Center, Oklahoma City (OK) 2016-. Available from: https://www.ncbi.nlm.nih.gov/ books/NBK343616/ [cited: 27 January 2020].

8. Szczypa K, Wilemska J, Hryniewicz W et al.: Epidemiologia zakażeń Streptococcus pyogenes, struktura klonalna populacji i antybiotykooporność. Post Mikrobiol 2013; 52: 223-232.

9. Bennett J, Moreland NJ, Oliver J et al.: Understanding group A streptococcal pharyngitis and skin infections as causes of rheumatic fever: protocol for a prospective disease incidence study. BMC Infect Dis 2019; 19: 633.

10. Fritz CQ, Edwards KM, Self WH et al.: Prevalence, risk factors, and outcomes of bacteremic pneumonia in children. Pediatrics 2019; 144: e20183090.

11. Suárez-Arrabal MC, Sánchez Cámara LA, Navarro Gómez ML et al. [Invasive disease due to Streptococcus pyogenes: changes in incidence and prognostic factors]. An Pediatr (Barc) 2019; 91: 286-295.

12. Couture-Cossette A, Carignan A, Mecier A et al.: Secular trends in incidence of invasive beta-hemolytic streptococci and efficacy of adjunctive therapy in Quebec, Canada, 1996-2016. PLoS One 2018; 13: e0206289.

13. Ochi F, Tauchi H, Jogamoto $\mathrm{T}$ et al.: Sepsis and pleural empyema caused by Streptococcus pyogenes after influenza A virus infection. Case Rep Pediatr 2018; 2018: 4509847.

14. Stevens DL, Bryant AE: Severe group A streptococcal infections. In: Ferretti JJ, Stevens DL, Fischetti VA (eds.): Streptococcus pyogenes: Basic Biology to Clinical Manifestations [Internet]. University of Oklahoma Health Sciences Center, Oklahoma City (OK) 2016-. Available from: https://www.ncbi.nlm.nih.gov/ books/NBK333425/ [cited: 27 January 2020].

15. Lynskey NN, Jauneikaite E, Li HK et al.: Emergence of dominant toxigenic M1T1 Streptococcus pyogenes clone during increased scarlet fever activity in England: a population-based molecular epidemiological study. Lancet Infect Dis 2019; 19: 1209-1218.

16. Saini N, Kumar D, Swarnim S et al.: Comparison of antistreptol$\mathrm{y} \sin \mathrm{O}$ and anti-deoxyribonucleic $\mathrm{B}$ titers in healthy children to those with acute pharyngitis, acute rheumatic fever, and rheumatic heart disease aged 5-15 years. Ann Pediatr Cardiol 2019; 12: 195-200.

17. Todd EW: Antigenic streptococcal hemolysin. J Exp Med 1932; 55: $267-280$.

18. Steer AC, Vidmar S, Ritika R et al.: Normal ranges of streptococcal antibody titers are similar whether streptococci are endemic to the setting or not. Clin Vaccine Immunol 2009; 16: 172-175.

19. Daniels R: Delmar's Guide to Laboratory and Diagnostic Tests: Organized Alphabetically, $2^{\text {nd }}$ ed., Delmar, Clifton Park, NY 2009.

20. Özlü SG, Yilmaz AÇ, Bülbül M et al.: Lobar pneumonia and glomerulonephritis: an unusual association. J Nephrol Renal Ther 2016; 2: 009.

21. Skrzypczyk P, Pańczyk-Tomaszewska M, Szymanik-Grzelak H: Ostre kłębuszkowe zapalenie nerek. Borgis - Nowa Pediatria 2009; 1: 27-32.

22. Liese JG, Schoen $\mathrm{C}$, van der Linden $\mathrm{M}$ et al.: Changes in the incidence and bacterial aetiology of paediatric parapneumonic pleural effusions/empyema in Germany, 2010-2017: a nationwide surveillance study. Clin Microbiol Infect 2019; 25: 857-864.

23. Kozłowska D, Myśliwiec H, Kiluk P et al.: Ocena kliniczna i epidemiologiczna pacjentów hospitalizowanych z powodu róży pierwotnej i nawrotowej. Przegl Epidemiol 2016; 70: 575-584. 